\title{
IDENTIFIKASI KARAKTERISTIK KEKAR BATUBARA LAPISAN BATUBARA D BERBASIS PENGAMATAN SINGKAPAN, KORELASI DATA LOG SONIK DAN KUALITAS MASSA BATUAN (RQD)
}

\author{
Characteristics Identification of Coal Seam D Based on Outcrop \\ Observation, and Correlation of Sonic Log and Rock Quality \\ Designation (RQD) Data
}

\author{
SARIF S. YUDHA dan ASEP B. PURNAMA \\ Puslitbang Teknologi Mineral dan Batubara \\ Jalan Jenderal Sudirman 623 Bandung 40211 \\ Telp. (022) 6030483, Fax. (022) 6003373 \\ e-mail: sarif.yudha@esdm.go.id
}

\begin{abstract}
ABSTRAK
Kekar batubara adalah rekahan alami di dalam lapisan batubara yang berperan penting dalam stimulasi pembentukan rongga pada proses gasifikasi batubara bawah permukaan. Oleh karena itu, penelitian mengenai karakteristik kekar batubara yang berkembang di dalam lapisan batubara penting dilakukan. Penelitian ini bertujuan untuk mengetahui karakteristik kekar batubara yang berada di daerah Macang Sakti, Musi Banyuasin, Sumatera Selatan, hubungan antara kekar batubara yang ada di permukaan dan kekar batubara yang berada di bawah permukaan. Objek yang diteliti adalah Lapisan Batubara D yang berada di konsesi pertambangan PT. Astaka Dodol. Penelitian ini dilakukan melalui pengambilan data lapangan dan mengorelasikan data pengamatan kekar batubara singkapan dengan data hasil pengeboran berupa data log sonik dan rock quality designation (RQD). Hasilnya, kekar batubara yang berada pada lapisan batubara tersebut merupakan kekar batubara endogenik, terlihat dari arah orientasinya yang relatif tegak lurus terhadap bidang perlapisan batubara. Frekuensi kekar muka pada lapisan batubara tersebut berkisar 10-20 kekar batubara tiap $2 \mathrm{~m}^{2}$. Dari data log sonik dan RQD, kekar batubara pada lapisan batubara umumnya berarah NNE-WSW dan berkembang mulai dari bagian atas sampai dengan bagian bawah Lapisan Batubara D dengan frekuensi kekar muka berkisar 10-20 kekar batubara pada area pengamatan $2 \mathrm{~m}^{2}$. Hal ini mengakibatkan perolehan dan nilai RQD yang jelek pada saat melakukan pengeboran inti. Lapisan batubara kurva log sonik mengalami naik-turun gelombang, sedangkan pada batuan lain relatif lebih konstan. Hal ini menunjukkan bahwa lapisan batubara tersebut memiliki karakteristik kekar batubara yang dominan.
\end{abstract}

Kata kunci: batubara, kekar batubara, log sonik

\begin{abstract}
Cleats are natural fractures in the coal seams, which play an important role in stimulating the formation of cavities in the subsurface coal gasification process. Therefore, research on the characteristics of cleats that develop in coal seams is important. The purpose of this study was to determine the characteristics of cleats in the Macang Sakti area, Musi Banyuasin, South Sumatera and the relationship between cleats on the surface and below the surface. The studied object is coal seam D which belongs to the mining concession of PT. Astaka Dodol. This research was conducted through field data retrieval and correlating data on coal cleat observation in
\end{abstract}


outcrops with drilling data in the form of sonic log data and rock quality designation data. As a result, the cleats in the coal seam are endogenic cleats, which can be observed from the orientation direction that is relatively perpendicular to the field of coal seam. The frequency of face cleats in the coal seams ranges from 10-20 cleats per $2 \mathrm{~m}^{2}$. From sonic log data and rock quality designation, these cleats generally have a direction of NNE-WSW that develop from the top to the bottom of the coal seam with a general orientation direction. The coal seam D develops from the top of the coal seams to the bottom of the coal seams with a face cleat frequency, ranging from 10-20 cleats in the observation area of $2 \mathrm{~m}^{2}$. This results in recovery and poor RQD values during core drilling. The sonic log curve coal seam experiences fluctuating waves, whereas in other rocks it is relatively more constant. This shows that the coal seam have the characteristics of the dominant cleat.

Keywords: coal, coal cleat, sonic log

\section{PENDAHULUAN}

Salah satu pemanfaatan batubara dengan metode nonkonvensional adalah menerapkan teknologi gasifikasi batubara bawah permukaan atau biasa disebut underground coal gasification (UCG), yang merupakan teknologi in-situ untuk mengekstraksi energi batubara yang tidak dapat ditambang secara konvensional (Kasani dan Chalaturnyk, 2017). Teknologi ini diklaim ramah lingkungan dalam pemanfaatan batubara untuk pembangkit listrik tenaga uap, karena batubara yang ada di bawah permukaan digasifikasi langsung secara in-situ menghasilkan produk berupa syngas yang akan diolah untuk berbagai macam keperluan.

Pada saat ini, Puslitbang Teknologi Mineral dan Batubara (Puslitbang tekMIRA) sedang mengembangkan teknologi UCG di daerah Musi Banyuasin, Sumatera Selatan (Purnama $d k k .$, 2017). Salah satu penelitian yang mendukung pengembangan teknologi UCG di daerah Musi Banyuasin adalah penelitian tentang kekar batubara di dalam lapisan batubara, karena informasi tentang kekar batubara dan data kuantitatifnya masih sangat terbatas (Kuncoro, 2012).

Kekar batubara adalah rekahan alami di dalam lapisan batubara yang secara umum terbagi menjadi dua, yaitu kekar muka dan ujung (butt cleats) (Gambar 1). Kekar muka adalah kekar batubara utama yang terdapat di dalam lapisan batubara, memiliki rekahan memanjang dan bukaan lebih lebar, sedangkan kekar ujung adalah sistem kekar batubara sekunder yang memiliki rekahan lebih pendek dan biasanya berakhir pada kekar muka. Pada beberapa lapisan batubara, kekar muka memanjang searah jurus batubara, namun di beberapa lapisan memanjang searah kemiringan batubara. Kedua jenis kekar batubara ini membentuk sudut siku satu sama lain (Laubach $d k k .$, 1998). Di dalam teknologi UCG, kekar batubara memegang peranan penting pada saat stimulasi pembentukan rongga antara sumur injeksi dan sumur produksi. Semakin banyak batubara, semakin efektif hubungan antara sumur injeksi dan sumur produksi (Shafirovich dan Varma, 2009).

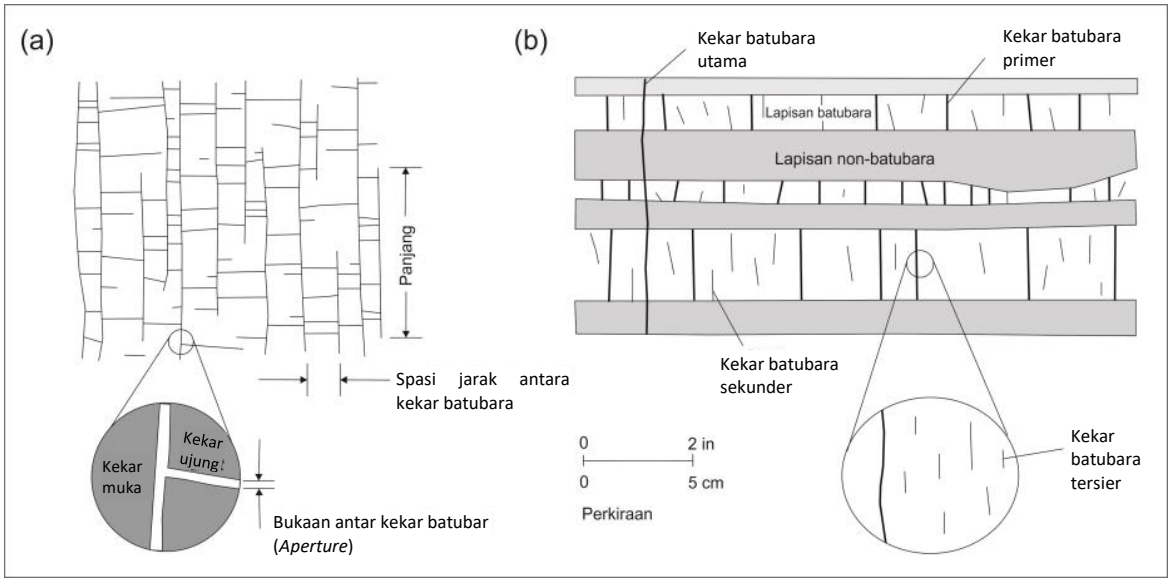

Gambar 1. Kenampakan kekar batubara dari atas dan secara vertikal (Laubach $d k k ., 1998)$ 
Puslitbang tekMIRA selama ini melakukan riset di daerah Musi Banyuasin, Sumatera Selatan (Purnama $d k k ., 2017$ ), tetapi belum menemukan karakteristik kekar batubara lapisan batubara yang akan dimanfaatkan untuk pengembangan UCG. Dengan demikian, penelitian mengenai karakteristik kekar batubara yang berkembang di area penelitian ini perlu dilakukan.

Penelitian ini bertujuan untuk mengetahui karakteristik kekar batubara Lapisan Batubara D yang berada di konsesi pertambangan PT. Astaka Dodol di daerah Macang Sakti, Musi Banyuasin, Sumatera Selatan serta hubungan antara kekar batubara yang ada di permukaan dan kekar batubara yang berada di bawah permukaan. Dengan mengorelasikan data pengamatan kekar batubara di singkapan dengan data hasil pengeboran, yaitu data log sonik dan data RQD pada lubang bor, maka akan didapatkan kesimpulan tentang karakteristik kekar batubara Lapisan Batubara D secara keseluruhan.

\section{METODE}

Lokasi penelitian berada di Desa Macang Sakti, Kecamatan Sanga Desa, Kabupaten Musi Banyuasin, Provinsi Sumatera Selatan (Gambar 2). Objek yang diteliti adalah lapisan batubara D, sementara itu karakteristik kekar batubara yang dikaji adalah arah umum penyebaran, frekuensi di setiap singkapan batubara, spasi (jarak) antar-kekar batubara, serta bukaan. Selain itu, terdapat data dukung berupa data RQD dan log sonik, sehingga penelitian ini berbeda dengan penelitian mengenai kekar batubara daerah lain (Kuncoro, 2012).

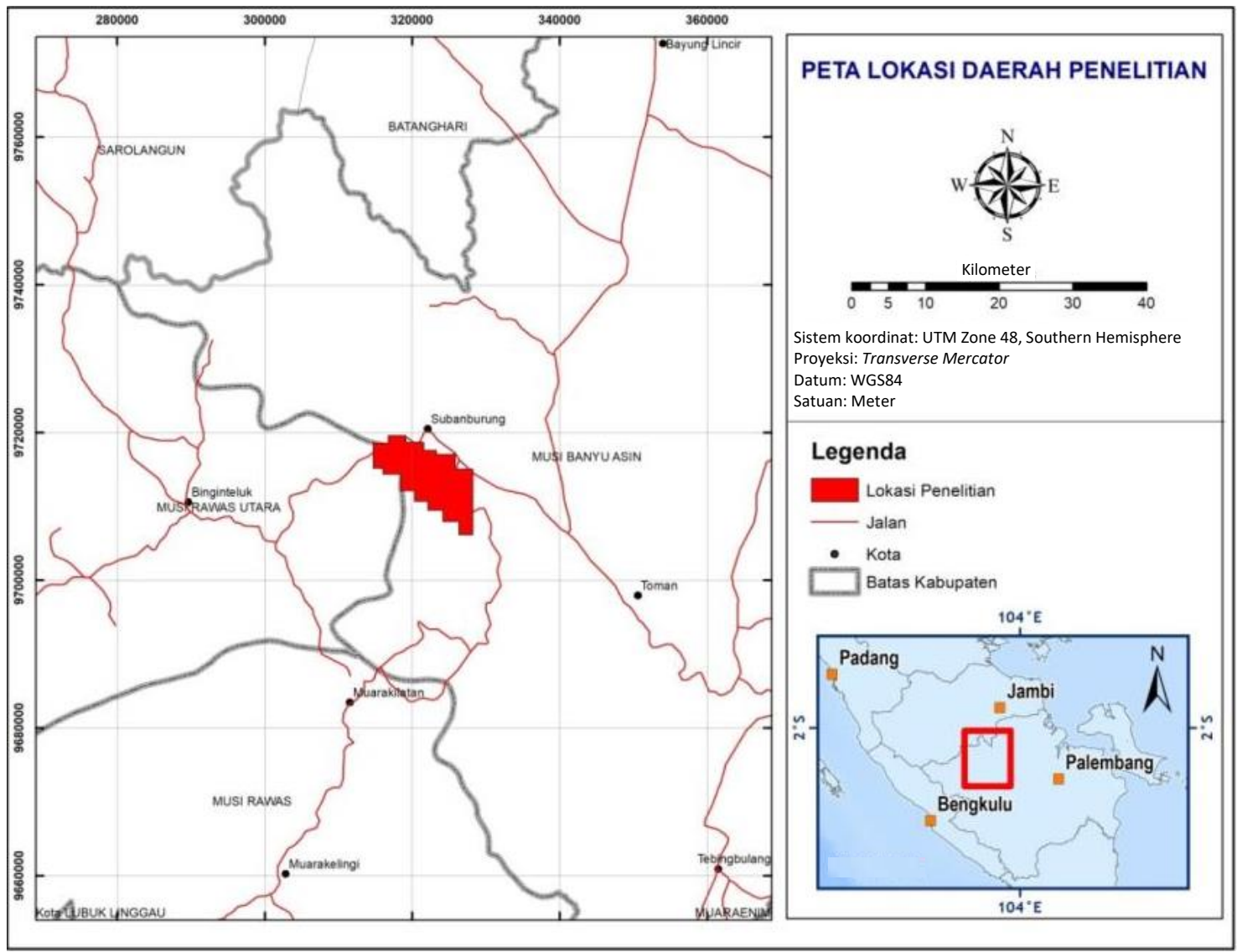

Gambar 2. Lokasi penelitian di daerah Macang Sakti, Musi Banyuasin, Sumatera Selatan 
Metode penelitian yang dilakukan dalam penelitian ini meliputi:

- Pengambilan data kekar batubara Lapisan Batubara D di dalam Blok A PT. Astaka Dodol dengan menggunakan kompas geologi dan meteran.

- Pengolahan data kekar batubara lapisan batubara tersebut menggunakan perangkat lunak dips.

- Pengambilan data pengeboran berupa data RQD dan log sonik.

- Analisis data pengeboran berupa data RQD dan log sonik lapisan batubara tersebut.

\section{GEOLOGI REGIONAL}

Lokasi penelitian berada pada daerah perbukitan bergelombang dengan kemiringan $3-15 \%$. Tata guna lahan berupa lahan masyarakat yang sudah beralih fungsi menjadi lahan perkebunan karet dan kelapa sawit.

Mengacu kepada Geologi Regional Lembar Sarolangun Skala 1:25.000 (Suwarna dkk., 1992), formasi yang terdapat pada daerah penelitian adalah Formasi Muara Enim (Gambar 3) dan Kasai; hampir sebagian besar daerah penelitian merupakan Formasi Muara Enim. Dari data geologi regional yang didukung dengan data hasil eksplorasi batubara di daerah penelitian, diketahui bahwa arah penyebaran batuan secara umum adalah barat laut-tenggara dengan arah kemiringan batuan berkisar $5-30^{\circ}$ ke arah barat daya.

Secara umum, litologi batuan yang terdapat di daerah penelitian didominasi oleh batulempung sisipan batupasir dan batubara yang termasuk ke dalam Formasi Muara Enim Anggota M2 pada bagian timur laut (updip) daerah penelitian dan batupasir sisipan batulanau dan batubara pada bagian barat daya (downdip) daerah penelitian (Gambar 4). Pada bagian paling barat daya daerah penelitian terdapat Formasi Kasai dengan litologi berupa batulempung pasiran dan terdapat sedikit tufaan. Secara umum, struktur geologi yang terdapat di daerah penelitian dikategorikan sebagai moderat, yaitu struktur geologi yang berkembang relatif sederhanaberupa monoklin dan diperkirakan terdapat sesar mendatar sinistral pada bagian tengah lokasi penelitian.

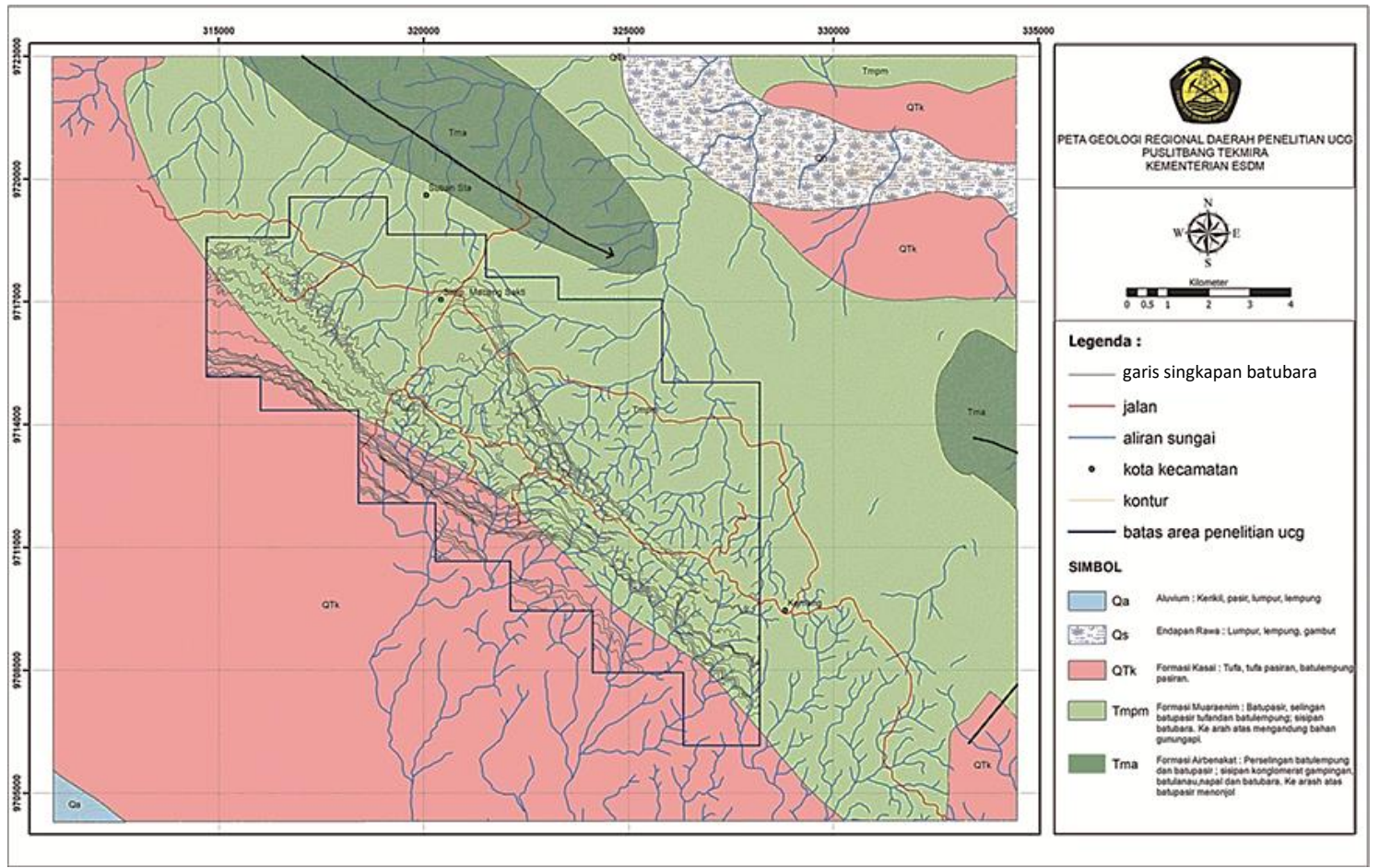

Gambar 3. Geologi regional daerah penelitian (modifikasi dari Suwarna dkk. (1992)) 


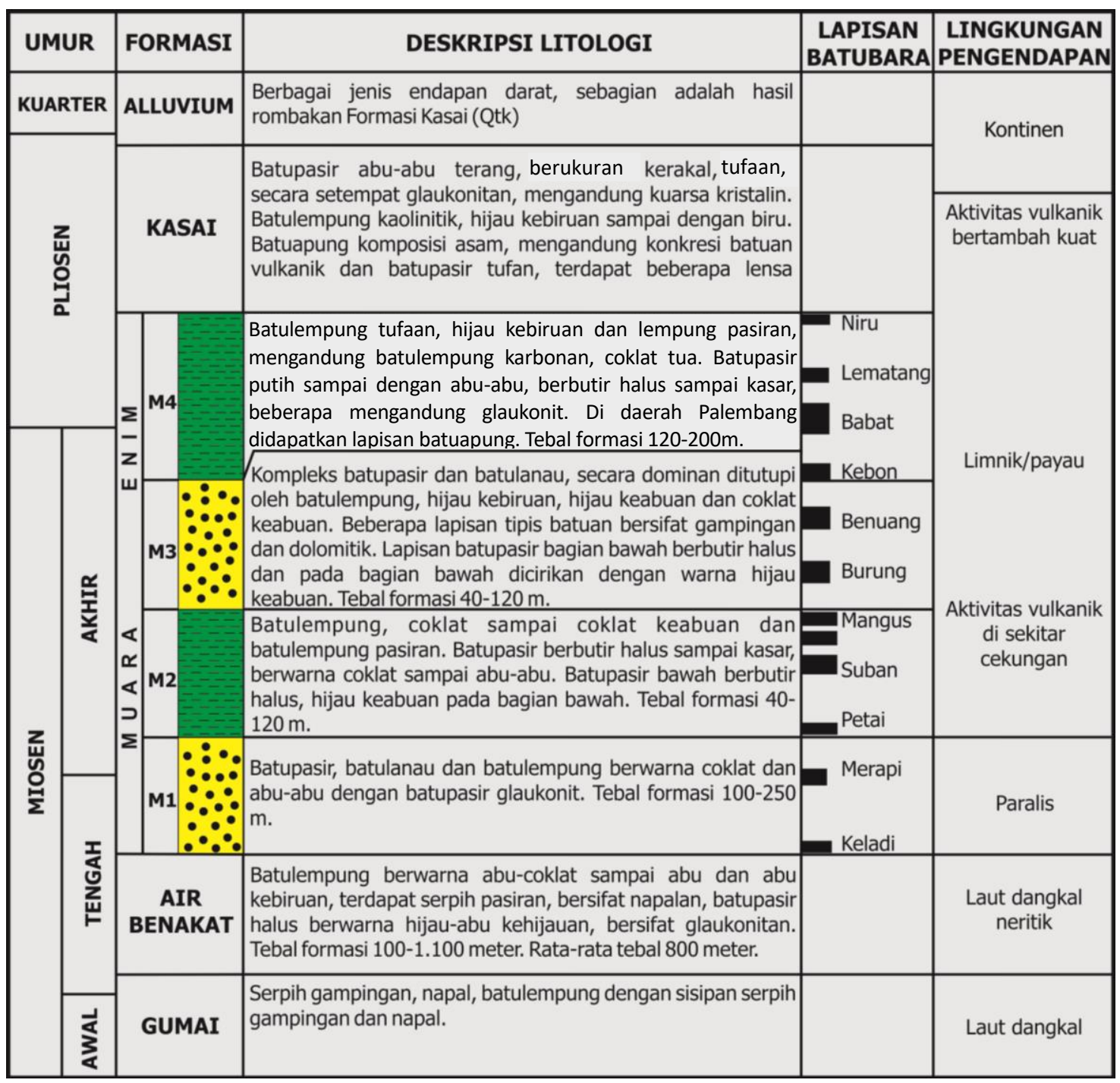

Gambar 4. Stratigrafi regional Formasi Muara Enim (modifikasi dari Minjbouw (1978))

\section{HASIL DAN PEMBAHASAN}

\section{Geologi Lokal}

Kondisi geomorfologi daerah penelitian berupa perbukitan sedang bergelombang dengan kemiringan berkisar $3-15^{\circ}$. Sebagian besar lahan yang terdapat pada daerah penelitian dimanfaatkan untuk areal perkebunan karet dan kelapa sawit.

Secara umum, batuan yang terdapat di dalam lokasi penelitian adalah batuan sedimen berumur Tersier yang didominasi oleh dua satuan batuan, yaitu Satuan Batupasir dan Satuan Batulempung Sisipan Batupasir, sementara batubara yang terdapat di lokasi penelitian merupakan sisipan dalam dua satuan batuan tersebut.

Lokasi penelitian memiliki kondisi geologis yang sederhana, yaitu struktur geologi yang berkembang hanya berupa monoklin dengan arah jurus atau arah umum penyebaran batuan relatif barat laut-tenggara dengan arah kemiringan lapisan batuan berkisar $10-30^{\circ}$ $\left(\mathrm{N} 120^{\circ} \mathrm{E} / 10-30^{\circ}\right)$. Hal tersebut didukung dari data korelasi lubang bor yang memperlihatkan bahwa tidak terdapat indikasi struktur geologi, dengan kondisi kontur struktur relatif normal dengan arah kemiringan lapisan ke barat daya. Kemungkinan arah kekar batubara yang berkembang tegak lurus atau searah penyebaran lapisan batubara. 
Secara umum, batubara yang terdapat di lokasi penelitian adalah batubara Formasi Muara Enim berumur Tersier, akan tetapi batubara yang diteliti hanya lapisan batubara D. Batubara ini mempunyai karakteristik warna coklat-kehitaman, gores coklat, kilap kusam dan pecahan subkonkoidal dengan sedikit pengotor berupa resin. Ketebalan batubara ini berkisar 8 sampai dengan $10 \mathrm{~m}$ pada lokasi lainnya, lapisan batubara ini terbagi menjadi beberapa bagian (splitting). Dari hasil analisis reflektan vitrinit, lapisan batubara D termasuk ke dalam peringkat lignit-subbituminus (Purnama dkk., 2017).

\section{Karakteristik Kekar Batubar}

Lokasi pengamatan kekar batubara berada di singkapan batubara yang umumnya memiliki lebar singkapan $2 \mathrm{~m}$ dengan panjang singkapan bervariasi searah kemiringan lapisan batubara. Singkapan berada di dasar sungai dengan luas area pengamatan sekitar 2 $\mathrm{m}^{2}$. Data karakteristik kekar batubara dapat dilihat pada Tabel 1.

Data tersebut kemudian dimasukkan dan diolah dengan perangkat lunak dips untuk mengetahui arah umum penyebaran kekar batubara muka dan ujung (Gambar 5). Berdasarkan hasil pengolahan data menggunakan perangkat lunak tersebut diketahui bahwa arah umum penyebaran kekar batubara muka berkisar 245-275 (NNE-WSW) dengan kemiringan bidang kekar batubara berkisar $70-80^{\circ}$, sementara arah umum penyebaran kekar batubara ujung berkisar $335-5^{\circ}$ dengan kemiringan bidang kekar batubara ujung berkisar 70-80.

Dari empat titik pengamatan di lapangan, jarak antar kekar batubara muka cukup bervariasi mulai dari $5 \mathrm{~cm}, 10 \mathrm{~cm}, 15 \mathrm{~cm}$, dan $20 \mathrm{~cm}$, sedangkan jarak kekar batubara ujung lebih pendek, yakni berkisar $3 \mathrm{~cm}, 5 \mathrm{~cm}$, sampai dengan $15 \mathrm{~cm}$. Panjang kekar batubara muka berkisar 2-2.5 meter dengan bukaan kekar batubara 1-3 mm, sedangkan kekar batubara ujung memiliki panjang yang relatif lebih pendek, yaitu berkisar $10-20 \mathrm{~cm}$ dengan bukaan yang relatif sama, yaitu 1$3 \mathrm{~mm}$.

Dari luasan pengamatan sekitar $2 \mathrm{~m}^{2}$, frekuensi kekar batubara yang muncul cukup banyak. Kekar batubara muka yang muncul di tiap titik pengamatan berkisar 10-20 kekar batubara dengan arah relatif sama, sedangkan kekar batubara ujung yang muncul relatif lebih banyak daripada kekar batubara muka.

Penelitian tentang kekar batubara dengan area penelitian yang lebih besar telah dilakukan di beberapa daerah lain di Indonesia. Penelitian tersebut antara lain dilakukan di daerah SatuiProvinsi Kalimantan Selatan, Palaran dan Busui-Provinsi Kalimantan Timur (Kuncoro, 2012), serta Cekungan Barito di Provinsi Kalimantan Selatan (Sapiie, Rifiyanto dan Perdana, 2014).

Tabel 1. Karakteristik kekar batubara hasil pengukuran di lapangan

\begin{tabular}{|c|c|c|c|c|}
\hline \multirow{2}{*}{ Kekar Batubara } & \multicolumn{4}{|c|}{ Lokasi } \\
\hline & ABP-01 & ABP-02 & ABP-03 & ABP-04 \\
\hline Panjang (cm) & $230-250$ & $200-250$ & $150-200$ & $50-100$ \\
\hline Tinggi $(\mathrm{cm})$ & 100 & 50 & 50 & 50 \\
\hline Bukaan (cm) & $0,1-0,3$ & $0,1-0,3$ & $0,1-0,3$ & $0,1-0,3$ \\
\hline $\begin{array}{l}\text { Jarak antar kekar } \\
\text { batubara }(\mathrm{cm})\end{array}$ & $5-20$ & $4-20$ & $5-20$ & $4-15$ \\
\hline Frekuensi kekar batubara & 10 & 17 & 12 & 12 \\
\hline $\begin{array}{l}\text { Kemiringan kekar } \\
\text { batubara }\left({ }^{\circ}\right)\end{array}$ & $65-75$ & $60-80$ & $70-80$ & $70-80$ \\
\hline $\begin{array}{l}\text { Orientasi (arah jurus } \\
\text { kekar batubara) }\end{array}$ & $\begin{array}{l}\text { timur laut- } \\
\text { barat daya }\end{array}$ & $\begin{array}{l}\text { timur laut- } \\
\text { barat daya }\end{array}$ & $\begin{array}{l}\text { barat laut- } \\
\text { tenggara }\end{array}$ & $\begin{array}{l}\text { barat laut- } \\
\text { tenggara }\end{array}$ \\
\hline Pengisi & - & - & - & - \\
\hline
\end{tabular}




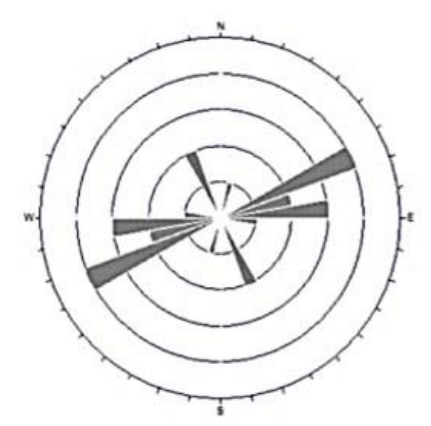

ABP-01

Kemiringan kekar batubara muka: $245-275^{\circ}$ Arah kemiringan: $\mathrm{N} 335^{\circ} \mathrm{E}$

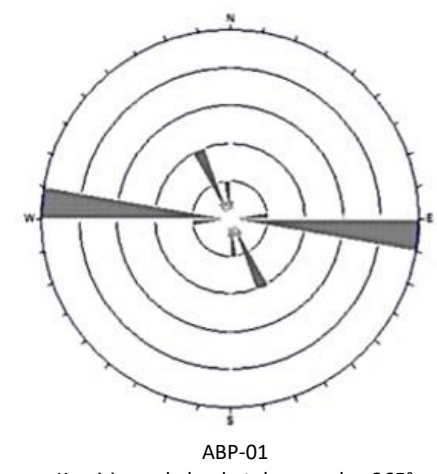

Kemiringan kekar batubara muka: $265^{\circ}$ Arah kemiringan: $\mathrm{N} 5^{\circ} \mathrm{E}$

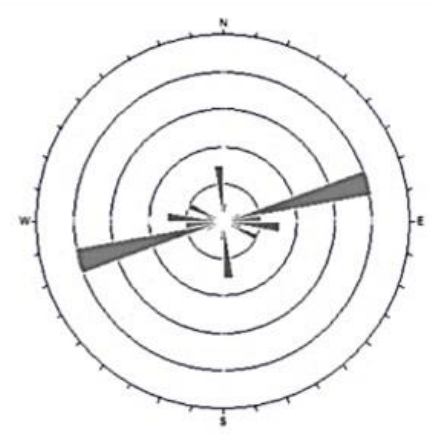

ABP-02

Kemiringan kekar batubara muka: $254-275^{\circ}$ Arah kemiringan: $\mathrm{N} 334^{\circ} \mathrm{E}$

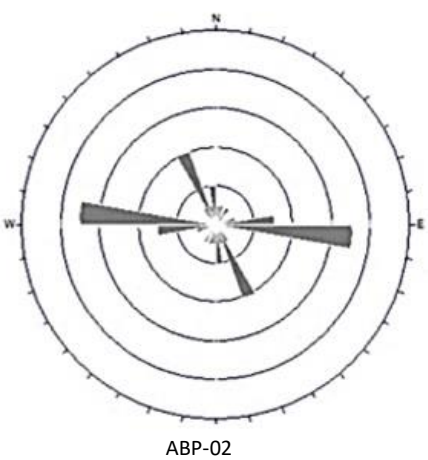

Kemiringan kekar batubara muka: $265^{\circ}$ Arah kemiringan: $\mathrm{N} 5^{\circ} \mathrm{E}$

Gambar 5. Hasil pengeplotan data kekar batubara ke dalam streonet menggunakan perangkat lunak dips

Penelitian kekar batubara di daerah Antiklin Satui dan Antiklin Palaran menunjukkan orientasi kekar batubara yang sejajar arah tegasan utama lipatan atau tegak lurus sumbu lipatan dengan frekuensi kekar batubara berkisar 16-19 kekar batubara pada sayap landai Antiklin Palaran, 18-25 kekar batubara pada sayap landai Antiklin Satui. Pada zona sesar, frekuensi kekar batubara yang muncul relatif lebih banyak dengan jarak antar kekar batubara relatif lebih pendek. Hal ini mengindikasikan bahwa pola kekar batubara di daerah Palaran dan Satui adalah kekar batubara sistematis yang dikendalikan oleh struktur lipatan dan sesar. Perbedaan karakteristik geometri kekar batubara di daerah lipatan dan sesar menunjukkan adanya hubungan genetik antara karakteristik kekar batubara dan struktur geologi yang berkembang (Kuncoro, 2012).
Penelitian lainnya tentang kekar batubara dalam skala yang lebih luas dilakukan di Cekungan Barito, Kalimantan Selatan (Sapiie, Rifiyanto dan Perdana, 2014). Penelitian ini bertujuan untuk melihat distribusi penyebaran kekar batubara secara regional. Dari hasil penelitian yang dilakukan di Cekungan Barito, ditarik beberapa kesimpulan antara lain:

1. Ada tiga arah orientasi utama penyebaran kekar batubara, yaitu WNW-ESE, NNWSSE dan NE-SW.

2. Jarak antar kekar batubara (kekar batubara semakin menurun dari batubara kalori rendah ke batubara kalori tinggi).

3. Beberapa batubara di Cekungan Barito mempunyai nilai permeabilitas dari 20-200 md, tetapi beberapa batubara mempunyai bukaan kekar batubara yang lebar $(>0,04$ $\mathrm{cm})$, dengan nilai permeabilitasnya mempunyai nilai lebih dari $2.000 \mathrm{md}$. 
Karakteristik kekar batubara yang berkembang di Musi Banyuasin, Sumatera Selatan dan di daerah Kalimantan Selatan maupun Cekungan Barito memiliki perbedaaan. Lapisan Batubara D yang berada di daerah penelitian, secara geologis termasuk ke dalam Formasi Muara Enim dengan kualitas batubaranya dikategorikan berperingkat rendah (Tobing, 2007) dengan nilai kalori berkisar 5.500-6.000 $\mathrm{kal} / \mathrm{gr}$ (adb) dan jarak antar-kekar batubara berkisar 4-20 cm. Batubara ini berbeda dengan batubara di daerah Satui-Kalimantan Selatan yang memiliki nilai kalori lebih tinggi berkisar $6.300 \mathrm{kal} / \mathrm{gr}(\mathrm{adb})$ (Friederich dan van Leeuwen, 2017) dengan jarak antar-kekar batubara berkisar 1-10 cm, bahkan pada beberapa sayap antiklin curam, jarak antar-kekar batubara berkisar 1-5 cm (Kuncoro, 2012). Selain daerah tersebut, karakteristik kekar batubara yang ada pada Lapisan Batubara D apabila dibandingkan dengan batubara di Cekungan Barito (Sapiie, Rifiyanto dan Perdana, 2014) dengan peringkat batubara subbituminus $\mathrm{C}$ dengan nilai kalori berkisar 5.000-8.000 kal/gr (adb) dengan spasi antar-kekar batubara berkisar 4-12 cm. Hal ini menunjukkan bahwa kualitas batubara dan struktur geologi yang berkembang di suatu daerah sangat memengaruhi karakteristik kekar batubara lapisan batubara.

Berdasarkann klasifikasi genetik kekar batubara batubara oleh Ammosov dalam Ryan (2003), kekar batubara Lapisan Batubara D termasuk dalam kategori kekar batubara endogenik yang dicirikan oleh orientasi kekar batubara muka yang hampir selalu tegak lurus bidang perlapisan, sehingga bidang kekar batubara membagi lapisan batubara menjadi fragmen tipis tabular.

\section{RQD dan Sonic Log}

RQD adalah pengukuran tingkat rekahan dalam inti bor (Lucian dan Wangwe, 2013). Dasar perhitungan dan pengklasifikasian nilai RQD menggunakan prosedur dan klasifikasi oleh Deere dan Deere (1989), seperti yang terlihat pada Gambar 6.

Dari perhitungan nilai RQD yang didapat di lapangan, kemudian diklasifikasikan sesuai dengan indeks klasifikasi RQD (Tabel 2).

Tabel 2. Indeks klasifikasi RQD

\begin{tabular}{cc}
\hline RQD & Kualitas massa batuan \\
\hline$<25 \%$ & Sangat buruk \\
$25-50 \%$ & Buruk \\
$50-75 \%$ & Cukup \\
$75-90 \%$ & Baik \\
$90-100 \%$ & Sangat baik \\
\hline
\end{tabular}

Berdasarkan prosedur pengukuran dan klasifikasi nilai RQD di atas, didapatkan data nilai klasifikasi RQD untuk Lapisan Batubara D di beberapa titik bor (Tabel 3).

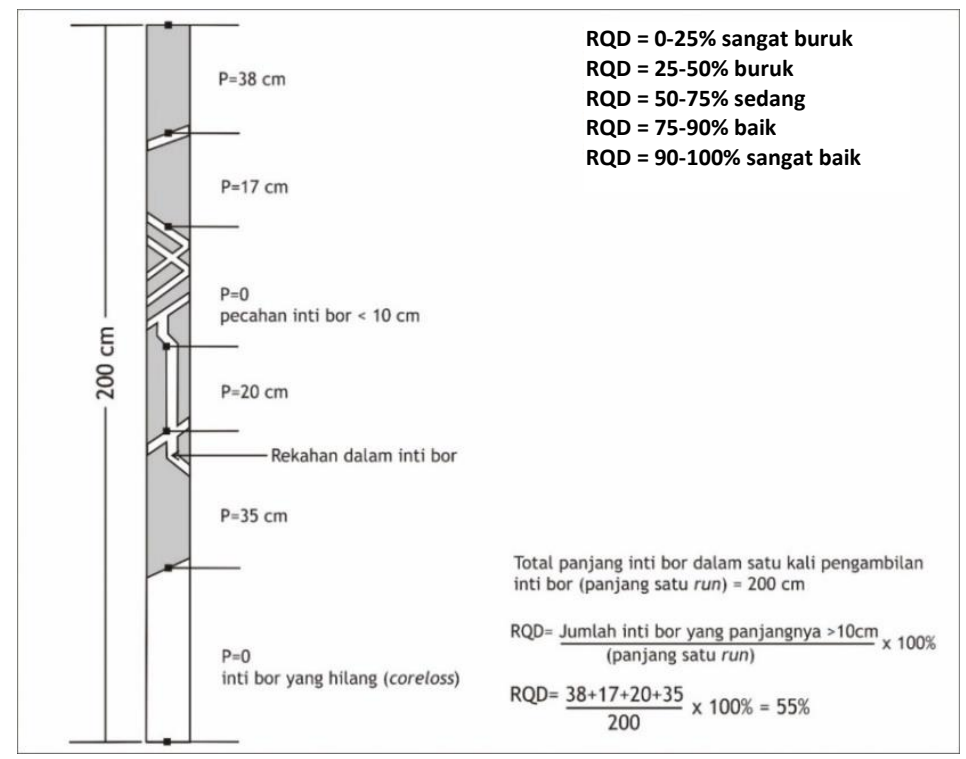

Gambar 6. Prosedur dan pengukuran RQD dari inti bor (Deere dan Deere, 1989) 
Tabel 3. Klasifikasi nilai kualitas massa batuan (RQM) berdasarkan indeks klasifikasi RQD

\begin{tabular}{|c|c|c|c|c|}
\hline \multirow{2}{*}{ Kode lubang bor } & \multicolumn{2}{|c|}{ Kedalaman (meter) } & \multirow{2}{*}{ RQD (\%) } & \multirow{2}{*}{$\begin{array}{l}\text { Kualitas Massa } \\
\text { Batuan (RQM) }\end{array}$} \\
\hline & Batas atas & Batas bawah & & \\
\hline \multirow{4}{*}{ UCG-07 } & 250,07 & 251,15 & 62,00 & Sedang \\
\hline & 251,15 & 245,15 & 24,00 & Sangat buruk \\
\hline & 254,15 & 257,15 & 34,33 & Buruk \\
\hline & 257,17 & 260,15 & 47,33 & Buruk \\
\hline \multirow{4}{*}{ UCG-09 } & 263,15 & 266,15 & 16,33 & Sangat buruk \\
\hline & 266,15 & 267,15 & 14,67 & Sangat buruk \\
\hline & 267,65 & 269,15 & 8,67 & Sangat buruk \\
\hline & 269,15 & 272,15 & 34,33 & Buruk \\
\hline \multirow{3}{*}{ UCG-11 } & 285,50 & 287,00 & 6,67 & Sangat buruk \\
\hline & 287,00 & 290,00 & 7,33 & Sangat buruk \\
\hline & 290,00 & 293,00 & 8,33 & Sangat buruk \\
\hline \multirow{3}{*}{ UCG-05 } & 239,90 & 242,05 & 29,30 & Buruk \\
\hline & 242,05 & 245,05 & 44,67 & Buruk \\
\hline & 245,05 & 248,05 & 19,67 & Sangat buruk \\
\hline
\end{tabular}

Dari nilai RQD di atas, Lapisan Batubara D dibagi menjadi tiga bagian untuk memudahkan korelasi nilai RQD masing-masing titik bor (Gambar 7), yaitu:

- bagian atas lapisan (0-3 m) nilai RQD berkisar dari 6,77 sampai dengan $62 \%$;

- bagian tengah lapisan (3-6 m) nilai RQD berkisar 7,33 sampai dengan $47 \%$;

- bagian bawah lapisan (6-9 meter) nilai RQD berkisar $6,67 \%$ sampai dengan $47,33 \%$.
Berdasarkan nilai RQD lapisan batubara D di beberapa titik bor, nilai RQD yang menunjukkan kualitas massa batuan yang cukup baik (fair) ada pada bagian atas titik bor UCG-07 D, sedangkan di titik bor lainnya menunjukkan kualitas massa batuan yang buruk, bahkan pada beberapa titik sangat buruk. Hal ini menunjukkan bahwa intensitas frekuensi kekar batubara dominan pada lapisan batubara D, sehingga memengaruhi nilai RQD pada lapisan batubara.

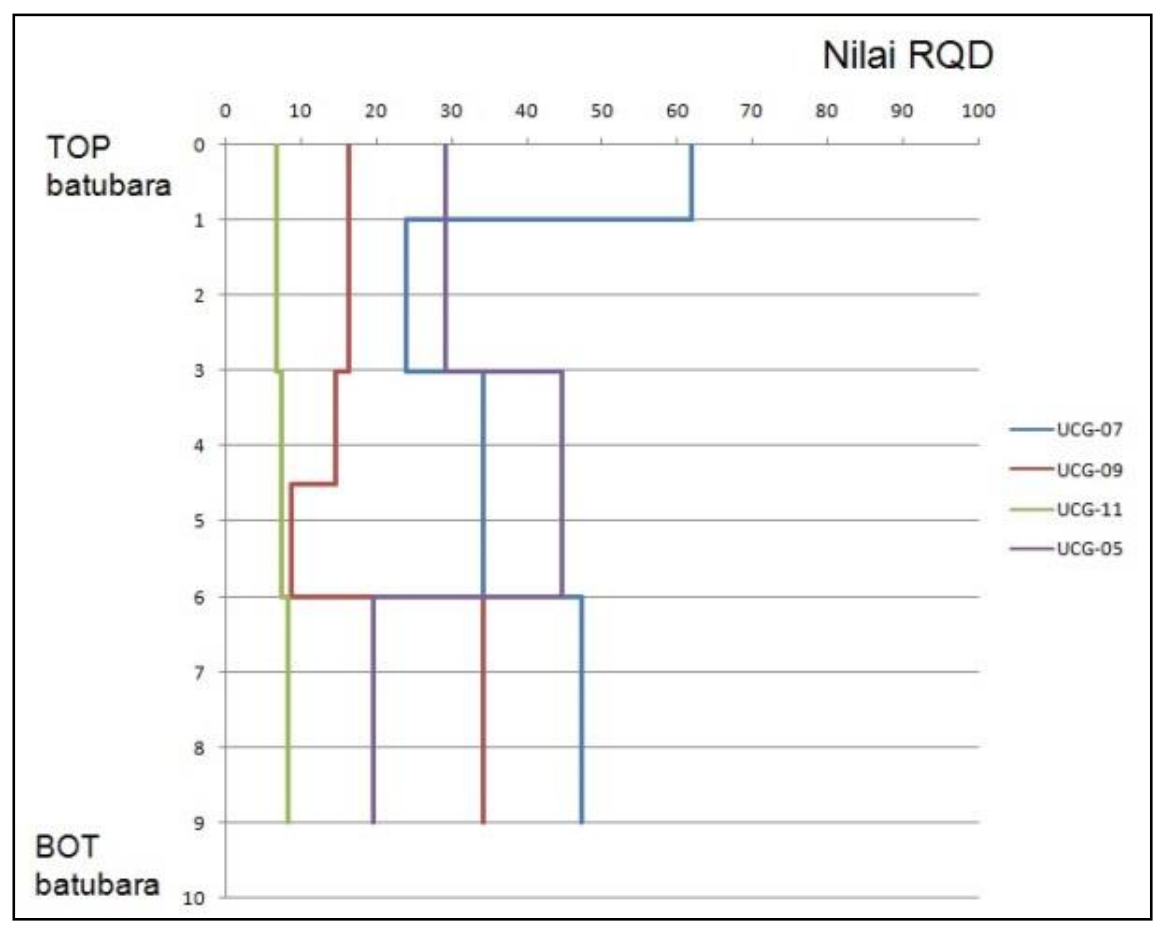

Gambar 7. Grafik nilai RQD lapisan batubara D di beberapa titik bor 
Tidak semua lubang bor dapat dilakukan pengambilan data log sonik. Hal ini disebabkan dinding lubang bor yang runtuh pada saat dilakukan pencatatan (logging), sehingga untuk pengambilan data log sonik dilakukan pada lubang bor lainnya pada lapisan batubara yang sama, yaitu Lapisan Batubara D. Berikut ini adalah hasil gambaran hasil log sonik pada lapisan batubara tersebut di titik 21 beserta responnya terhadap log gamma ray, log density dan spontaneous potential log (SP Log), seperti terlihat pada Gambar 8. Salah satu kegunaan log sonik adalah untuk mengetahui porositas suatu batuan dengan melihat besarnya nilai transite time yang dihasilkan dari setiap jenis batuan. Apabila nilai transite time semakin besar, maka porositas batuan tersebut semakin besar. Sebaliknya, apabila nilai transite time semakin kecil, maka batuan tersebut memiliki porositas yang jelek. Porositas dalam batubara dipengaruhi berbagai hal, salah satunya adalah adanya kekar batubara di dalam batubara. Semakin banyak kekar batubara yang terbentuk dalam batubara, semakin besar nilai porositas dan permeabilitas batubara tersebut. Dari grafik log sonik dapat dilihat bahwa pada lapisan batubara kurva sonic log mengalami kenaikan nilai $\mu \mathrm{S}$, sedangkan pada batulempung dan batulanau yang lebih kompak dan inpermeabel, kurva log sonik relatif lebih konstan.

Dari log sonik dapat dilihat bahwa nilai waktu tempuh gelombang persatuan mikro-kaki/kaki ataupun nilai $\mu$ s mengalami kenaikan (Gambar 9). Hal tersebut berarti cepat rambat gelombang suara menembus lapisan batuan mengalami penurunan. Selain itu, defleksi kurvanya menggambarkan naik turunnya nilai cepat rambat gelombang, sedangkan pada lapisan batubara yang relatif kompak nilai defleksi kurva relatif rata. Dengan demikian dapat diinterpretasikan bahwa pada Lapisan Batubara D terdapat kekar batubara mulai dari lapisan atas sampai dengan lapisan bawah batubara, meskipun variasi frekuensi kekar batubara yang berkembang bervariasi di tiap titik bor.

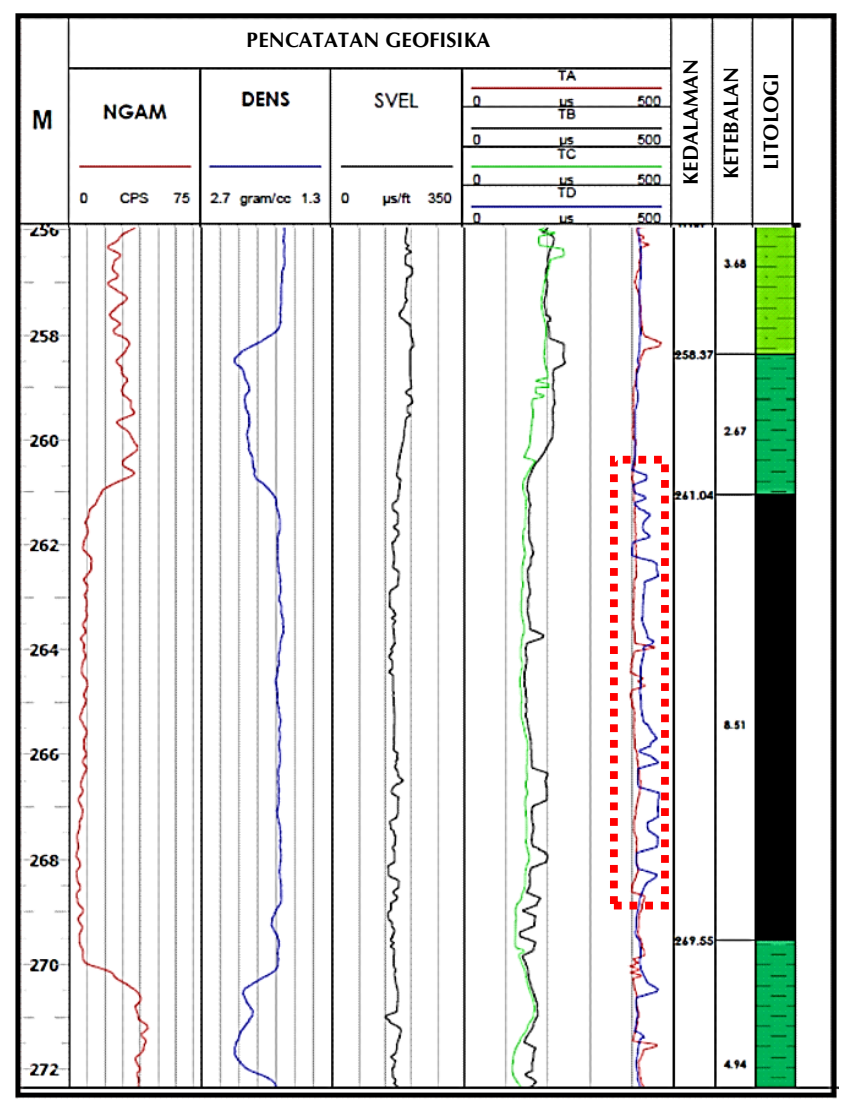

Gambar 8. Respon berbagai log geofisika terhadap lapisan batubara D di titik UCG 21. Pada log sonik di kotak berwarna merah, kurva mengalami naik-turun nilai gelombang, sedangkan pada batuan lain relatif lebih konstan 


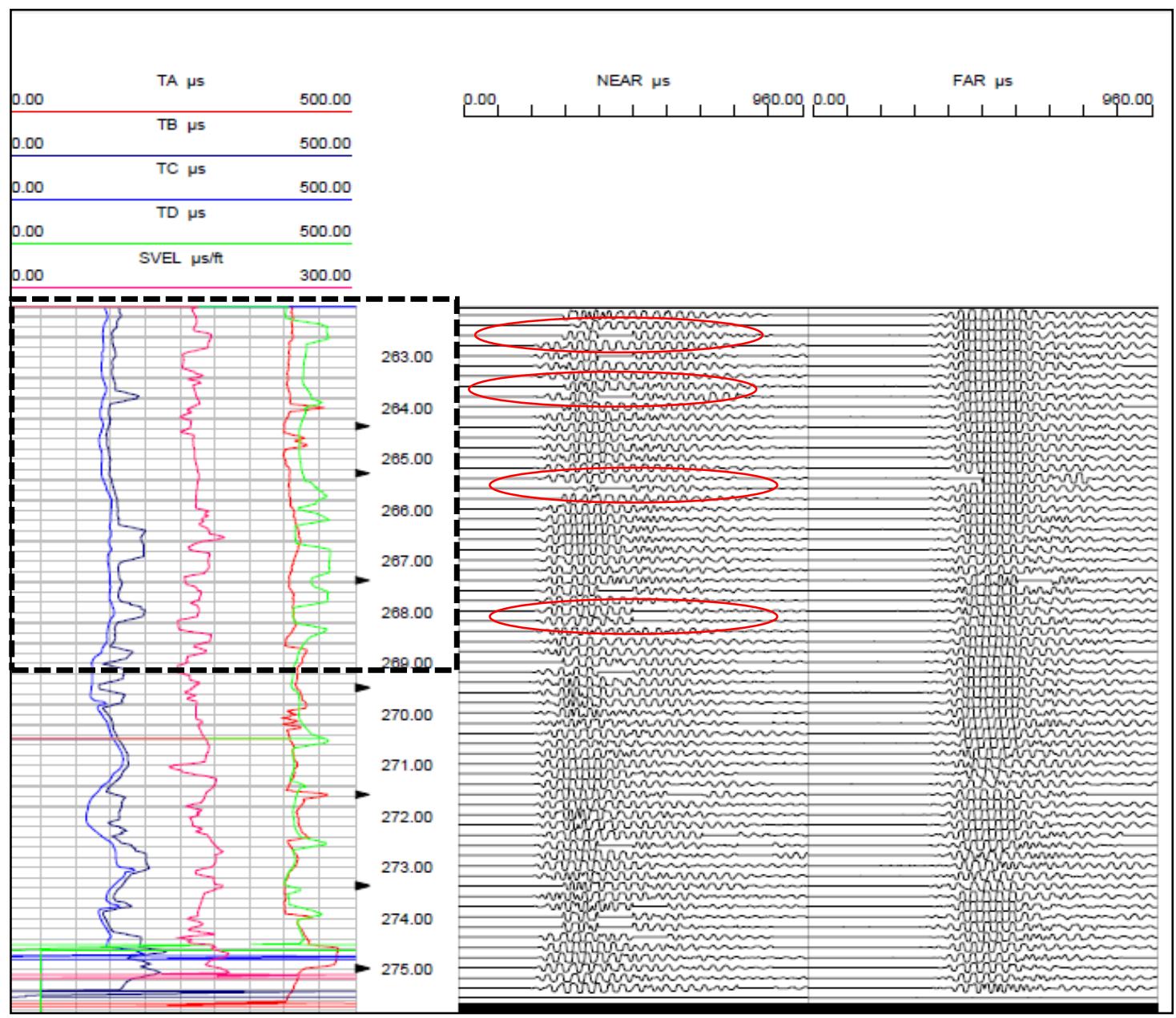

Gambar 9. Log sonic lapisan batubara D pada titik UCG-21. Zona-zona yang berwarna merah menandakan adanya kekar batubara di dalam lapisan batuan

\section{KESIMPULAN DAN SARAN}

\section{Kesimpulan}

Dari hasil penelitian kekar batubara pada lapisan batubara D di daerah Macang Sakti, Musi Banyuasin, Sumatera Selatan didapatkan kesimpulan sebagai berikut:

1. Arah umum orientasi kekar muka berkirsar 245-275 (NNE-WSW) dengan kemiringan bidang kekar muka berkisar 70-80.

2. Kekar batubara yang berkembang pada lapisan batubara D merupakan kekar batubara endogenik, terlihat dari arah orientasi face cleat yang relatif tegak lurus bidang perlapisan batubara.

3. Karakteristik kekar batubara lapisan batubara D berbeda dengan karakteristik kekar batubara di daerah Kalimantan
Selatan dan Cekungan Barito karena perbedaan kualitas batubara dan struktur geologi yang berkembang.

4. Karakteristik kekar batubara pada Lapisan Batubara D berkembang mulai dari bagian atas lapisan batubara sampai dengan bagian bawah lapisan batubara dengan frekuensi kekar muka berkisar 10-20 kekar batubara pada area pengamatan $2 \mathrm{~m}^{2}$. Hal ini mengakibatkan perolehan dan nilai RQD yang jelek pada saat melakukan pengeboran inti.

5. Pada lapisan batubara kurva log sonik mengalami naik-turun gelombang, sedangkan pada batuan lain relatif lebih konstan. Hal ini menunjukkan bahwa lapisan batubara tersebut memiliki karakteristik kekar batubara yang dominan. 


\section{UCAPAN TERIMA KASIH}

Penulis mengucapkan banyak terima kasih kepada rekan-rekan yang telah membantu selama pengambilan data di lokasi penelitian serta kepada Puslitbang tekMIRA yang telah menyediakan sarana dan prasarana penelitian. Tidak lupa penulis mengucapkan banyak terima kasih kepada pihak PT. Astaka Dodol yang telah memberikan fasilitas selama penelitian.

\section{DAFTAR PUSTAKA}

Deere, D. U. dan Deere, D. W. (1989) Rock quality designation (RQD) after twenty years. National Technical Information Service.

Friederich, M. C. dan van Leeuwen, T. (2017) "A review of the history of coal exploration, discovery and production in Indonesia: The interplay of legal framework, coal geology and exploration strategy," International Journal of Coal Geology, 178, hal. 56-73. doi: 10.1016/j.coal.2017.04.007.

Kasani, H. A. dan Chalaturnyk, R. J. (2017) "Coupled reservoir and geomechanical simulation for a deep underground coal gasification project," Journal of Natural Gas Science and Engineering, 37, hal. 487-501. doi: 10.1016/j.jngse.2016.12.002.

Kuncoro, P. B. (2012) "Cleat pada lapisan batubara dan aplikasinya di dalam industri pertambangan," in Prosiding Simposium Dan Seminar Geomekanika Ke-1. Yogyakarta: Universitas Pembangunan Nasional "Veteran" Yogyakarta, hal. 101.

Laubach, S. E., Marrett, R. A., Olson, J. E. dan Scott, A. R. (1998) "Characteristics and origins of coal cleat: A review," International Journal of Coal Geology, 35(1-4), hal. 175-207. doi: 10.1016/S0166-5162(97)00012-8.

Lucian, C. dan Wangwe, E. M. (2013) "The usefulness of rock quality designation (RQD) in determining strength of the rock," International Refereed Journal of Engineering and Science, 2(9), hal. 36-40. Tersedia pada: http://www.irjes.com/Papers/vol2issue9/F02093640.pdf.

Minjbouw, S. N. V. (1978) "Geological map of the South Sumatra coal Province."

Purnama, A. B., Subarna, Y. S., Sendjadja, Y. A., Muljana, B. dan Santoso, B. (2017) "Potensi batubara untuk pengembangan gasifikasi bawah permukaan : Studi kasus Desa Macang Sakti, Provinsi Sumatera Selatan," Jurnal Teknologi Mineral dan Batubara, 13(1), hal. 13-30.

doi: 10.30556/jtmb.Vol13.No1.2017.156.

Ryan, B. (2003) "Cleat development in some British Columbia coals," in Geological Fieldwork 2002. British Columbia Geological Survey, hal. 237-255. Tersedia pada: https://www.semanticscholar.org/paper/CleatDevelopment-in-Some-British-ColumbiaCoalsRyan/e68809c9e6f159b09d25af7015e1b3c0 de019a74.

Sapiie, B., Rifiyanto, A. dan Perdana, L. A. (2014) "Cleats analysis and CBM potential of the Barito Basin, South Kalimantan, Indonesia," in AAPG International Conference \& Exhibition. Istanbul: AAPG, hal. 1-19.

Shafirovich, E. dan Varma, A. (2009) "Underground coal gasification: A brief review of current status," Industrial \& Engineering Chemistry Research, 48(17), hal. 7865-7875. doi: 10.1021/ie801569r.

Suwarna, N., Suharsono, Gafoer, S., Amin, T. C., Kusnama dan Hermanto, B. (1992) "Peta geologi lembar Sorolangun, Sumatera, Skala 1:250.000." Bandung: Pusat Penelitian dan Pengembangan Geologi.

Tobing, S. M. (2007) "Survei pendahuluan potensi gas dalam batubara daerah Tamiang, Kabupaten Musi Banyuasin, Propinsi Sumatra Selatan," in Prosiding Pemaparan Hasil Kegiatan Lapangan Dan Non Lapangan Tahun 2007. Bandung: Pusat Sumber Daya Geologi, hal. 1-10. 